\title{
The impact of monitoring and sanctioning on unemployment exit and job-finding rates
}

\section{Job search monitoring and benefit sanctions generally reduce unem- ployment duration and boost entry to employment in the short term}

Keywords: unemployment, job search, sanctions, monitoring

\section{ELEVATOR PITCH}

Unemployment benefits reduce incentives to search for a job. Policymakers have responded to this behavior by setting minimum job search requirements, by monitoring to check that unemployment benefit recipients are engaged in the appropriate level of job search activity, and by imposing sanctions for infractions. Empirical studies consistently show that job search monitoring and benefit sanctions reduce unemployment duration and increase job entry in the short term. However, there is some evidence that longer-term effects of benefit sanctions may be negative.

\section{KEY FINDINGS}

\section{Pros}

๑ Most developed countries have some form of job search monitoring for unemployment benefit recipients and a system of benefit sanctions for infractions.

๑ Even just the threat of benefit sanctions can reduce unemployment duration and increase job entry rates.

๑ Being sanctioned reduces unemployment duration following the sanction and increases the rate of job entry.

๑ Job search monitoring leads to shorter unemployment duration and higher job entry rates in the short term.

\section{Sanctions and unemployment benefit exits, UK}

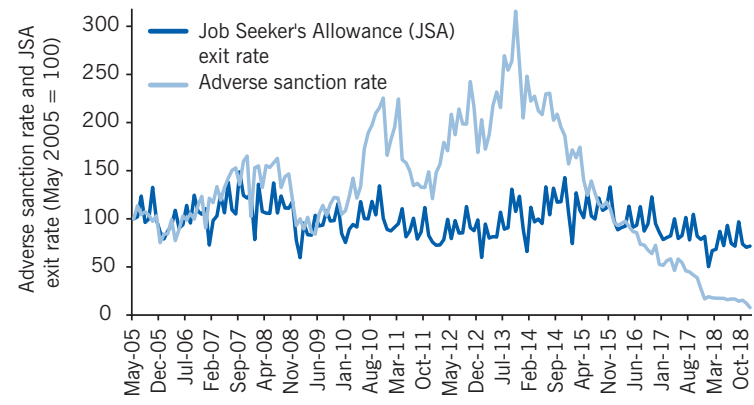

Source: Author's own calculations based on data from NOMIS: https: //www.nomisweb.co.uk/; UK Department for Work and Pensions: https: //www.gov.uk/government/organisations/department-for-work-pensions I Z A $\int$

\section{Cons}

- Job search monitoring imposes a cost on monitored individuals.

- Sanctions can further reduce income, at least in the short term, for those already on low incomes.

- There is some evidence that being sanctioned can lead to withdrawal from the labor force and a reduction in post-unemployment earnings.

- More research is needed to examine the effects of monitoring and sanctions in a wider range of contexts, on a wider range of outcomes, and over a longer time frame.

\section{AUTHOR'S MAIN MESSAGE}

Job search monitoring imposes a cost on monitored individuals and benefit sanctions impose a cost on sanctioned individuals. Yet evidence consistently shows that job search monitoring and benefit sanctions reduce the duration of unemployment and increase the rate of job entry, making them potentially attractive policy options. On the other hand, there is some evidence that such measures can drive people out of the labor force and may reduce the quality of job matches. Substantial gaps in the evidence base remain, however, particularly concerning the longerterm effects of monitoring and sanctions on job quality. 


\section{MOTIVATION}

Job search monitoring and sanctions for failing to search actively enough are widely used in OECD countries. These measures are intended to counteract the search disincentive effects of unemployment insurance. But do they work?

\section{Job search monitoring and sanctions}

Job search monitoring is the process of checking whether unemployed workers are engaging in sufficient search activity to qualify to receive unemployment benefits or unemployment insurance. This can mean checking up on search methods, time spent searching, and employer contacts made. Monitoring is usually backed up by the threat of withdrawing benefits (sanctions) for people who are not sufficiently active in their job search. Benefit sanctions may also be imposed for declining a suitable job offer or for other administrative infractions.

Economic theory posits that such measures will increase search intensity and reduce the reservation wage (the wage below which a person prefers to remain unemployed), thereby increasing the exit rate from unemployment benefits and the job entry rate [1]. Unlike with training programs, there is no reason to expect lock-in effects-effects that reduce job search while people are participating in the program-from monitoring and sanctions [2]. On the other hand, tougher monitoring or stricter sanctions may lead job seekers to substitute formal (monitored) job search for informal (unmonitored, such as word-of-mouth) job search, which could have ambiguous effects on unemployment duration and job entry rates, depending on which type of search is more effective [2]. Further, the reduction in the reservation wage may lead to lower quality job matches. Monitoring and sanctions might also drive some unemployed workers out of the labor force altogether.

This theoretical ambiguity makes empirical evidence particularly important. There is a growing body of studies that provides credible evidence, although substantial gaps remain. All of the studies reviewed here were published in the last 20 years, reflecting the widespread adoption of such measures only since the 1990s.

\section{DISCUSSION OF PROS AND CONS}

Most unemployment benefit systems have had basic eligibility requirements since their inception, such as being available for work, registering with the employment service, and accepting suitable job offers. But only since the mid-1990s have most OECD countries coupled these requirements with job search monitoring and sanctions for infractions.

The regularity of job search monitoring and the toughness of benefit sanctions (in terms of their duration, coverage, and severity) vary across countries and over time and sometimes for different unemployment benefit types within countries. For example, the UK requires fortnightly proof of job search activity at face-to-face meetings with advisors, while Poland requires no formal evidence of job search activity at all. Similarly, refusing a (first, suitable) job offer leads to complete cancellation of benefits in Portugal but only suspension for one week in Sweden. There is also variation across and within countries 
in the extent to which sanctions are enforced, although this is more difficult to quantify. This variation may itself be associated with the toughness of sanctions and other aspects of the unemployment insurance regime, such as the duration of benefits. In recent years there has been no clear cross-country increasing or decreasing trend in the toughness of monitoring or sanctions, although some countries have relaxed aspects of their regimes (e.g. Australia Denmark) while others have tightened aspects of theirs (e.g. Italy, Finland).

Both job search monitoring and benefit sanctions impose costs on covered individuals. They also entail administrative costs. The trade-off, of course, is that they may reduce unemployment duration and increase job entry. Even just the threat of benefit sanctions can, in theory, reduce unemployment duration and increase job entry. However, if sanctioned individuals end up making lower-quality job matches than would otherwise have been the case, and if some of those exiting unemployment as a result of monitoring and/or sanctions move out of the labor force rather than into employment, the shortterm gains from such measures may come at the cost of long-term pain. Fortunately, there is a growing body of credible empirical evidence, from around the world, which has begun to quantify these effects and which can therefore help to inform policymakers about the pros and cons of these kinds of interventions.

\section{Empirical evidence on the impact of search monitoring}

Although there is an extensive empirical literature on the combined effects of reforms of search requirements, monitoring, and search assistance for unemployment benefit recipients, there are fewer studies that separately distinguish the effects of changes in job search monitoring from changes in these other aspects of the benefit regime. This literature has focused on the effects of monitoring on benefit recipients, mostly ignoring potential monitoring effects on inflows to unemployment, with some exceptions [3].

Seven studies that credibly separate the effects of monitoring from those of other aspects of unemployment benefit reform packages and from selection effects are reviewed here (Figure 1). Three of the studies randomly assigned subjects into treatment and control groups (randomized controlled trials, RCT)-two in the US and one in Hungary. The remaining four studies used quasi-experimental approaches that exploit non-random but plausibly exogenous assignment to treatment and control groups to identify monitoring effects.

\section{Selection effects}

Selection effects are differences in observed and unobserved characteristics between those who experience a change in the monitoring regime and those who do not, which are themselves correlated with outcomes. In the case of sanctions, they are differences in the observed and unobserved characteristics between those who receive a sanction and those who do not.

Four of the seven studies report positive and statistically significant effects of job search monitoring on unemployment exit rates and/or job entry rates, corresponding with reduced unemployment duration. The magnitude of these estimated effects vary-there are differences in the extent of the changes in monitoring being studied-but in a fairly 
Figure 1. Empirical studies of the effects of job search monitoring

\begin{tabular}{l}
\hline Study \\
\hline Klepinger, \\
D. H., T. R. Johnson, \\
and J. M. Joesch. \\
"Effects of unemployment \\
insurance work search \\
requirements: The \\
Maryland experiment." \\
Industrial and Labor \\
Relations Review
\end{tabular}

56 (2002): 3-22 [3]

Ashenfelter,

O., D. Ashmore, and

O. Deschenes.

"Do unemployment

insurance recipients

actively seek work?

Evidence from randomized

trials in four US states."

Journal of Econometrics

125 (2005): 53-75 [6]

McVicar, D. "Job

search monitoring

intensity,

unemployment exit and

job entry: Quasi-

experimental evidence

from the UK." Labour

Economics 15 (2008):

1451-1468 [4]

McVicar, D. "Does job

search monitoring

intensity affect

unemployment?

Evidence from Northern

Ireland." Economica 77

(2010): 296-313

Micklewright, J., and

G. Nagy. "The effect

of monitoring

unemployment

insurance recipients

on unemployment

duration: Evidence

from a field

experiment." Labour

Economics 17 (2010):

180-187 [7]

Cockx, B., and

M. Dejemeppe.

"Monitoring job search

effort: An evaluation

based on a regression

discontinuity design."

Labour Economics

19 (2012):

729-737 [5]

\begin{tabular}{|c|c|c|c|}
\hline Where and when & Data & Study type & Key results \\
\hline $\begin{array}{l}\text { US (Maryland, } \\
\text { six unemployment } \\
\text { offices), } 1994\end{array}$ & $\begin{array}{l}\text { Administrative } \\
n=23,758, \\
\text { unemployment } \\
\text { insurance entrants } \\
\text { tracked for one year, } \\
\text { wage data for up to } \\
\text { one year after } \\
\text { unemployment } \\
\text { insurance exit }\end{array}$ & Experiment & $\begin{array}{l}\text { Moving from no } \\
\text { monitoring to tough } \\
\text { monitoring: } \\
\text { - Reduces benefit } \\
\text { duration by } 10 \% \\
\text { - No effect on earnings }\end{array}$ \\
\hline $\begin{array}{l}\text { US, one local } \\
\text { area in each of } \\
\text { four states, } \\
\text { 1984-1985 }\end{array}$ & $\begin{array}{l}\text { Administrative, } \\
\text { supplemented } \\
\text { with } \\
\text { information on } \\
\text { job applications, } \\
n=4,632\end{array}$ & Experiment & $\begin{array}{l}\text { Monitoring intensity: } \\
\text { - No significant effect } \\
\text { on benefit duration }\end{array}$ \\
\hline
\end{tabular}

UK (Northern

Ireland),

1999-2005

Administrative, $n=388,359$

unemployment benefit spells

for 171,598

individuals

Natural

experiment

(roll out of

regime

change

across local

areas)

Withdrawal of monitoring:

- Increases benefit duration by $10-16 \%$ as a result of reduced job entry and reduced switching to other benefits

UK (Northern Ireland),

1997-2005

Unemployment benefit register data, aggregated to 35 local areas; observed monthly for 100 months, $n=3,500$

Natural experiment (roll out of

Withdrawal of monitoring people receiving across local benefits by $8-12 \%$ as a areas) result of reduced outflows

$\begin{array}{ll}\text { Hungary } & \text { Administrative } \\ \text { (six counties), } & n=2,134\end{array}$

Experiment

Increased monitoring intensity:

- No significant effect on benefit duration or job entry, on average

- Increases to entry rate for women aged $30+$ by $50 \%$

- Size of effect is negatively correlated with local unemployment rate

$\begin{array}{ll}\text { Belgium } & \text { Administrative } \\ \text { (Flanders), } & n=2,240\end{array}$

Regression discontinuity design

Tougher monitoring regime phased in by age group:

- Increase in job entry

within eight months

by $23 \%$ (marginally

statistically significant)

- No effect on labor

force withdrawal 
Figure 1. Continued

\begin{tabular}{|c|c|c|c|c|}
\hline Study & Where and when & Data & Study type & Key results \\
\hline $\begin{array}{l}\text { Lombardi, S. Threat } \\
\text { Effects of Monitoring } \\
\text { and Unemployment } \\
\text { Insurance Sanctions: } \\
\text { Evidence from Two } \\
\text { Reforms. IFAU Working } \\
\text { Paper No. 22, } 2019\end{array}$ & $\begin{array}{l}\text { Sweden, } \\
2011-2015\end{array}$ & $\begin{array}{l}\text { Administrative, } \\
n=29,536 \\
\text { unemployment } \\
\text { assistance } \\
\text { spells }\end{array}$ & $\begin{array}{l}\text { Natural } \\
\text { experiment } \\
\text { (different } \\
\text { reform timing } \\
\text { by benefit } \\
\text { type) }\end{array}$ & $\begin{array}{l}\text { Tougher monitoring: } \\
\text { - } 21 \% \text { increase in the job } \\
\text { entry rate for male long- } \\
\text { term unemployed } \\
\text { - No effect for women }\end{array}$ \\
\hline
\end{tabular}

Source: Author's own compilation.

narrow range. For example, one study finds that tougher monitoring leads to a $10 \%$ reduction in unemployment benefit duration [3], another finds a $10-16 \%$ reduction in unemployment duration [4], and a third finds a $23 \%$ increase in the probability of finding employment within eight months [5].

One study reports positive but statistically insignificant monitoring effects on unemployment exit rates, which may reflect the combination of small sample size and fairly minor changes to monitoring intensity [6]. The other two studies find mixed results by gender, with one finding an effect on job entry rates for women aged 30 years and above but no overall effect [7], and the other-a recent working paper examining Swedish reforms-finding an effect on job entry rates for men but not for women. The first of these two studies also finds evidence that the size of the monitoring effect on job entry varies negatively with the local unemployment rate [7].

A few of the studies look at the effects of monitoring on other outcomes, with mixed results. One finds a significant effect on switching from unemployment benefits to other welfare benefits, interpreted as a move out of the labor force [4]. A recently released study using data for Belgium suggests a similar effect, with increased monitoring of unemployment benefit recipients driving some to switch to disability benefits. Another study finds no effect on dropping out of the labor force [5]. One study examines monitoring effects on earnings in the year following the initiation of the unemployment insurance claim, and finds little impact [3]. It also finds no significant effect on the probability of re-entering unemployment within a year. A recently released study using data for the Netherlands suggests tougher monitoring does lead to lower wages in the (re-)entry job, but that subsequent job mobility compensates for this adverse long-term effect over time. Another study, using data from Northern Ireland, finds a small reduction in inflows to unemployment resulting from suspension of search monitoring, perhaps caused indirectly by reduced outflows from unemployment and the resulting removal of high-risk individuals from the at-risk population.

\section{Empirical evidence on the effect of benefit sanctions}

The sanctions literature has concentrated on estimating the effects of sanctions imposed on current recipients of unemployment benefits, mostly ignoring the effect of eligibility restrictions (such as voluntarily leaving a job) on inflows. Sanctions on unemployment benefit recipients can be imposed for failing to search actively for a new job, rejecting a suitable job offer or offer of a placement in an employment or training program, and for violating other administrative requirements, such as failing to show up for advisor interviews. 
Both the threat of sanctions (the "ex ante or threat effect") and the imposition of sanctions (the "ex post effect") can affect the behavior of unemployed workers receiving benefits. Most of the sanctions literature focuses on the ex post effects, despite the potential importance of ex ante effects. In jurisdictions where workers who have committed an unemployment insurance program infraction receive warning letters before a sanction is imposed (notably Switzerland), the ex post sanction effect can be separated into a "warning effect" (that a sanction is or may be coming) and an "imposition effect" once the sanction has been imposed.

Figure 2 summarizes 12 empirical studies of the effects of sanctions that have a clear strategy for dealing with the main identification problem: separating the effects of sanctions from the effects of differences in observed and unobserved characteristics between unemployed workers who receive a sanction and those who do not (selection effects). Specifically, it seems likely that unemployed workers who receive a sanction have characteristics that would otherwise reduce their probability of unemployment exit or job entry [8], [9]. Failure to account for this selection effect is likely to lead to underestimates of the effects of benefit sanctions on these outcomes.

In the absence of RCT of sanctions, the studies rely on econometric analysis of administrative data, and most use the timing-of-events approach to estimate the ex post effects of sanctions. This approach exploits the exact timing of sanction events to identify causal effects. Although the approach is not without its critics, it is widely used and accepted in applied economics research.

All of the in-scope studies examine effects of sanctions using European data, and nearly all adopt the timing-of-events approach. These studies all find that receiving a sanction significantly increases the rate of exit from unemployment benefits, the rate of job entry, or both. The magnitude of these measured effects varies, but two upper-end estimates suggest that receiving a sanction more than doubles the unemployment benefit exit rate and the job entry rate [8], [9]. In Switzerland, unemployment benefit recipients receive sanction warning letters in advance of the imposition of a sanction, so the two studies using Swiss data are able to separately identify the effect of receiving a warning letter from that of receiving a sanction [2], [10]. The studies find similar effects in both cases on the unemployment benefit exit rate and the job entry rate.

Some studies examine evidence for heterogeneous effects of receiving a sanction on job entry and/or unemployment exit rates. Here evidence is mixed and appears to be context-specific. One study, for Sweden, finds a larger sanction effect on job entry for women than for men [11], while another Swedish study (a recent working paper) finds no difference by gender. Another, for Finland, finds a stronger effect for men than for women [12]. Two studies for the Netherlands find larger positive effects on the job entry rate and benefit exit rate for women than for men [1], [13]. One of them also finds differences in sanction effects across different (sectoral) unemployment insurance agencies [1]. Some studies also suggest differences in sanction effects by age [11], immigrant status [9], marital status [9], and unemployment benefit type [13].

Examinations of whether the effects of sanctions vary by when in the unemployment spell they are imposed find mixed results. For Germany, one study finds that the effect of sanctions is weaker the further into the unemployment benefits period it is imposed. A study for the Netherlands finds a similar pattern for women, but the opposite for men [13]. Two studies find that the effect of receiving a sanction diminishes over the time that has elapsed since the sanction was imposed. Another study finds no effect of elapsed time [11]. 
Figure 2. Empirical studies of the impacts of sanctions

\begin{tabular}{|c|c|c|c|c|}
\hline Study & Where and when & Data & Study type & Key results \\
\hline $\begin{array}{l}\text { van den Berg, G., B. } \\
\text { van der Klaauw, and } \\
\text { J. C. van Ours. } \\
\text { "Punitive sanctions } \\
\text { and the transition } \\
\text { rate from welfare } \\
\text { to work." Journal } \\
\text { of Labor Economics } \\
22(2004) \text { : } \\
211-241 \text { [8] }\end{array}$ & $\begin{array}{l}\text { Netherlands } \\
\text { (Rotterdam), } \\
\text { 1994-1996 }\end{array}$ & $\begin{array}{l}\text { Administrative, } \\
n=7,978 \text { spells } \\
\text { (unemployed on } \\
\text { social assistance) }\end{array}$ & $\begin{array}{l}\text { Timing-of-events } \\
\text { model }\end{array}$ & $\begin{array}{l}\text { Receiving a sanction: } \\
\text { - Increases job entry rate } \\
\text { by } 140 \%\end{array}$ \\
\hline $\begin{array}{l}\text { Abbring, J. H., G. van } \\
\text { den Berg, and J. C. van } \\
\text { Ours. "The effect of } \\
\text { unemployment } \\
\text { insurance sanctions on } \\
\text { the transition rate from } \\
\text { unemployment to } \\
\text { employment." Economic } \\
\text { Journal } 115 \text { (2005): } \\
602-630[1]\end{array}$ & $\begin{array}{l}\text { Netherlands, } \\
\text { 1992-1993 }\end{array}$ & $\begin{array}{l}\text { Administrative, } \\
n=\text { (up to) } \\
40,973 \text { spells, } \\
\text { in } 16 \text { out of } 19 \\
\text { unemployment } \\
\text { agencies }\end{array}$ & $\begin{array}{l}\text { Timing-of-events } \\
\text { model }\end{array}$ & $\begin{array}{l}\text { Receiving a sanction: } \\
\text { - Increasing job entry rate } \\
\text { by } 58 \% \text { for men and } 67 \% \\
\text { for women } \\
\text { - Significant differences across } \\
\text { unemployment insurance } \\
\text { agencies }\end{array}$ \\
\hline $\begin{array}{l}\text { Lalive, R., J. C. van Ours, } \\
\text { and J. Zweimuller. } \\
\text { "The effects of benefit } \\
\text { sanctions on the } \\
\text { duration of } \\
\text { unemployment." } \\
\text { Journal of the European } \\
\text { Economic Association } \\
\text { 3 (2005): } \\
\text { 1386-1417 [10] }\end{array}$ & $\begin{array}{l}\text { Switzerland } \\
\text { (three cantons), } \\
1997-1999\end{array}$ & $\begin{array}{l}\text { Administrative } \\
\text { data, } \\
n=10,404 \\
\text { spells }\end{array}$ & $\begin{array}{l}\text { Timing-of-events } \\
\text { model; local } \\
\text { area variations } \\
\text { in regime } \\
\text { toughness }\end{array}$ & $\begin{array}{l}\text { Receiving a sanction warning lette } \\
\text { - Increases unemployment } \\
\text { benefit exit rate by } 23 \% \\
\text { Receiving a sanction: } \\
\text { - Increases unemployment } \\
\text { benefit exit rate by } 20 \% \\
\text { Stronger threat of sanctions: } \\
\text { - Reduces claim duration: a one } \\
\text { standard deviation increase in } \\
\text { the warning rate reduces claim } \\
\text { duration by five days }\end{array}$ \\
\hline $\begin{array}{l}\text { Müller, K. U., and } \\
\text { V. Steiner. Imposed } \\
\text { Benefit Sanctions and } \\
\text { the Unemployment-to- } \\
\text { Employment Transition: } \\
\text { The German Experience. } \\
\text { IZA Discussion Paper } \\
\text { No. 3483, } 2008\end{array}$ & $\begin{array}{l}\text { Germany, } \\
\text { 2001-2005 }\end{array}$ & $\begin{array}{l}\text { Administrative, } \\
n=318,889 \\
\text { spells for } \\
314,206 \\
\text { individuals, } \\
\text { tracked for up } \\
\text { to four years }\end{array}$ & $\begin{array}{l}\text { Propensity score } \\
\text { matching and } \\
\text { hazard model }\end{array}$ & $\begin{array}{l}\text { Receiving a sanction: } \\
\text { - Positive effect on job entry } \\
\text { rate, diminishing over time } \\
\text { Receiving a sanction in first } \\
\text { three months: } \\
\text { - Lowers the unemployment } \\
\text { benefit survival rate by } 8 \% \text { at } \\
\text { the end of three months; } \\
\text { effects diminish over time } \\
\text { until sanction is imposed }\end{array}$ \\
\hline $\begin{array}{l}\text { van den Berg, G., and } \\
\text { J. Vikström. "Monitoring } \\
\text { job offer decisions, } \\
\text { punishments, exit to } \\
\text { work, and job quality." } \\
\text { Scandinavian Journal } \\
\text { of Economics 116: } \\
2 \text { (2014): 284- } \\
334 \text { [11] }\end{array}$ & $\begin{array}{l}\text { Sweden, } \\
\text { 1999-2004 }\end{array}$ & $\begin{array}{l}\text { Administrative } \\
\text { (unemployment } \\
\text { and employment } \\
\text { register data), } \\
n=16,491 \\
\text { individuals } \\
\text { (with 35,055 } \\
\text { spells) }\end{array}$ & $\begin{array}{l}\text { Timing-of-events } \\
\text { model }\end{array}$ & $\begin{array}{l}\text { Receiving a sanction: } \\
\text { - Increases job entry rate by } 23 \% \\
\text { - Effects are smaller for men than } \\
\text { women, and for older workers } \\
\text { than for younger workers; no } \\
\text { difference by education or local } \\
\text { unemployment rate } \\
\text { - Effects do not diminish rapidly } \\
\text { over time } \\
\text { - Lowers wages by } 3.8 \% \text {, an } \\
\text { effect that persists up to four } \\
\text { years (as far as the data go) } \\
\text { - Increases the probability of a } \\
\text { part-time rather than full-time job } \\
\text { by } 15 \% \text { (ten percentage points) } \\
\text { - Reduces the occupational level } \\
\text { by } 0.04 \text { years of schooling } \\
\text { required to do the job }\end{array}$ \\
\hline $\begin{array}{l}\text { Svarer, M. "The effect } \\
\text { of sanctions on exit } \\
\text { from unemployment: } \\
\text { Evidence from } \\
\text { Denmark." Economica } \\
78(2011) \text { : } \\
751-778 \text { [9] }\end{array}$ & $\begin{array}{l}\text { Denmark, } \\
\text { 2003-2005 }\end{array}$ & $\begin{array}{l}\text { Administrative, } \\
n=219,348 \\
\text { spells (for } \\
164,962 \\
\text { individuals) }\end{array}$ & $\begin{array}{l}\text { Timing-of-events } \\
\text { model }\end{array}$ & $\begin{array}{l}\text { Receiving a (first) sanction: } \\
\text { - Increases the unemployment } \\
\text { benefit exit rate by }>100 \% \\
\text { for both men and women } \\
\text { - Some groups are more } \\
\text { responsive than others (male } \\
\text { immigrants compared to } \\
\text { male natives, marrieds } \\
\text { compared to singles) }\end{array}$ \\
\hline
\end{tabular}


Figure 2. Continued

\begin{tabular}{|c|c|c|c|c|}
\hline Study & Where and when & Data & Study type & Key results \\
\hline & & & & $\begin{array}{l}\text { - Effect disappears after } \\
\text { three months } \\
\text { - Tentative evidence that } \\
\text { sanction amount is positively } \\
\text { linked to exit effect }\end{array}$ \\
\hline $\begin{array}{l}\text { Hofmann, B. } \\
\text { "Short- and } \\
\text { long-term ex post } \\
\text { effects of } \\
\text { unemployment } \\
\text { insurance sanctions." } \\
\text { Journal of Economics } \\
\text { and Statistics } 232 \\
(2012): 31-60 .\end{array}$ & $\begin{array}{l}\text { Germany, } \\
\text { 2000-2001 }\end{array}$ & $\begin{array}{l}\text { Administrative, } \\
n \approx 400,000 \\
\text { spells }\end{array}$ & $\begin{array}{l}\text { Propensity } \\
\text { score } \\
\text { matching }\end{array}$ & $\begin{array}{l}\text { Receiving a sanction: } \\
\text { - For women, increases number } \\
\text { of months employed in regular } \\
\text { jobs over } 12 \text { months by up to } 0.9 \\
\text { months, and in other jobs by up } \\
\text { to } 0.6 \text { months, with no effect on } \\
\text { time out of the labor force } \\
\text { - For men, increases number of } \\
\text { months employed in regular jobs } \\
\text { by up to } 0.8 \text { months, decreases } \\
\text { number of months in other jobs } \\
\text { by up to } 0.2 \text { months, and } \\
\text { increases number of months } \\
\text { out of the labor force by } \\
\text { up to } 0.7 \text { months }\end{array}$ \\
\hline $\begin{array}{l}\text { Arni, P., R. Lalive, } \\
\text { and J. C. van Ours. } \\
\text { "How effective are } \\
\text { unemployment benefit } \\
\text { sanctions? Looking } \\
\text { beyond unemployment } \\
\text { exit." Journal of Applied } \\
\text { Econometrics 28:7 } \\
\text { (2013): 1153-1178 [2] }\end{array}$ & $\begin{array}{l}\text { Switzerland, } \\
\text { 1998-2003 }\end{array}$ & $\begin{array}{l}\text { Administrative } \\
n=23,961 \\
\text { spells }\end{array}$ & $\begin{array}{l}\text { Timing-of-events } \\
\text { model }\end{array}$ & $\begin{array}{l}\text { Receiving a sanction warning: } \\
\text { - Increases job entry rate by } \\
17 \% \text { and exit from the labor } \\
\text { force by } 89 \% \\
\text { - Lowers earnings (when } \\
\text { combined with receiving a } \\
\text { sanction) by } 9 \% \\
\text { Receiving a sanction: } \\
\text { - Increases job entry rate by } \\
16 \% \text { and exit from the labor } \\
\text { force by } 67 \% \\
\text { - Reduces earnings (combined } \\
\text { with warning) by } 9 \% \text { and } \\
\text { job duration by } 15 \% \\
\text { Being in a high-sanction area: } \\
\text { - Increases job entry and } \\
\text { reduces earnings }\end{array}$ \\
\hline $\begin{array}{l}\text { Hillmann, K., and } \\
\text { I. Hohenleitner } \\
\text { Impact of } \\
\text { Benefit Sanctions } \\
\text { on Unemployment } \\
\text { Outflow: Evidence } \\
\text { from German } \\
\text { Survey Data. } \\
\text { Hamburg Institute } \\
\text { of International } \\
\text { Economics } \\
\text { Research Paper } \\
\text { No. 129, } 2012\end{array}$ & $\begin{array}{l}\text { Germany, } \\
\text { 2005-2007 }\end{array}$ & $\begin{array}{l}\text { Panel household } \\
\text { survey data, } \\
n=3,996 \text { spells } \\
\text { for } 3,599 \\
\text { individuals on } \\
\text { unemployment } \\
\text { assistance }\end{array}$ & $\begin{array}{l}\text { Timing of events } \\
\text { model }\end{array}$ & $\begin{array}{l}\text { Receiving a sanction: } \\
\text { - Increases job entry rate by } \\
68 \% \text { and labor force exit } \\
\text { rate by } 79 \%\end{array}$ \\
\hline $\begin{array}{l}\text { van der Klaauw, B., } \\
\text { and J. C. van Ours. } \\
\text { "Carrot and stick: } \\
\text { How re-employment } \\
\text { bonuses and benefit } \\
\text { sanctions affect exit } \\
\text { rates from welfare." } \\
\text { Journal of Applied } \\
\text { Econometrics } \\
28 \text { (2013): } \\
275-296 \text { [13] }\end{array}$ & $\begin{array}{l}\text { Netherlands } \\
\text { (Rotterdam), } \\
\text { 2000-2003 }\end{array}$ & $\begin{array}{l}\text { Administrative, } \\
n=30,527 \\
\text { spells for } \\
28,039 \\
\text { individuals }\end{array}$ & $\begin{array}{l}\text { Timing of events } \\
\text { model }\end{array}$ & $\begin{array}{l}\text { Receiving a sanction: } \\
\text { - Increases exit rate by } 21 \% \text { for } \\
\text { men and } 47 \% \text { for women } \\
\text { - Effect larger for married men } \\
\text { than for single men } \\
\text { Receiving a sanction } \\
\text { during first year: } \\
\text { - For men has smaller effects } \\
\text { than sanctions imposed later } \\
\text { - For women has larger effects } \\
\text { than sanctions imposed } \\
\text { later }\end{array}$ \\
\hline
\end{tabular}


Figure 2. Continued

\begin{tabular}{|c|c|c|c|c|}
\hline Study & Where and when & Data & Study type & Key results \\
\hline $\begin{array}{l}\text { Busk, H. } \\
\text { "Sanctions and } \\
\text { the exit from } \\
\text { unemployment in } \\
\text { two different benefit } \\
\text { schemes." Labour } \\
\text { Economics (2019) } \\
\text { 42: 159-176 [12] }\end{array}$ & $\begin{array}{l}\text { Finland, } \\
\text { 2003-2009 }\end{array}$ & $\begin{array}{l}\text { Administrative, } \\
n=464,550 \\
\text { spells }\end{array}$ & $\begin{array}{l}\text { Timing of events } \\
\text { model }\end{array}$ & $\begin{array}{l}\text { Receiving a sanction: } \\
\text { - Increases the job entry rate } \\
\text { among flat-rate unemployment } \\
\text { assistance recipients by } 84 \% \\
\text { - Increases the job entry rate } \\
\text { among earnings-related } \\
\text { unemployment insurance } \\
\text { recipients by } 25 \% \\
\text { - Effects are bigger for men than } \\
\text { for women } \\
\text { - Longer sanctions have bigger } \\
\text { effects } \\
\text { - Increases the rate of exit from } \\
\text { the labor force, with a larger } \\
\text { effect for women than for men }\end{array}$ \\
\hline $\begin{array}{l}\text { Lombardi, S. Threat } \\
\text { Effects of Monitoring } \\
\text { and Unemployment } \\
\text { Insurance Sanctions: } \\
\text { Evidence from Two } \\
\text { Reforms. IFAU } \\
\text { Working Paper } \\
\text { No. } 22,2019\end{array}$ & $\begin{array}{l}\text { Sweden, } \\
\text { 2011-2015 }\end{array}$ & $\begin{array}{l}\text { Administrative, } \\
n=29,536\end{array}$ & $\begin{array}{l}\text { Timing of events } \\
\text { model }\end{array}$ & $\begin{array}{l}\text { Receiving a sanction: } \\
\text { - Increases the job entry rate } \\
\text { by } 29 \% \\
\text { - No difference by gender }\end{array}$ \\
\hline
\end{tabular}

Source: Author's own compilation.

Although the duration and severity of sanctions vary across countries, other crosscountry differences make it difficult to draw general conclusions about the relationships among sanction duration, severity, and effects from this source. Some studies have exploited within-regime variation in sanction severity to examine this issue-with, again, mixed findings. One study finds no evidence for significant differences in effects between sanctions of different severity, although there is only limited variation in sanction severity in their data [8]. Two studies-one for Denmark and one for Finland-find evidence that more severe (e.g. longer duration) sanctions have larger effects on the exit rate from unemployment benefits and the job entry rate, respectively [9], [12].

A few studies look at the effects of sanctions on other outcomes. Some find significant positive effects of sanctions on the probability of leaving the labor force [2], [12]. A study on Sweden finds negative effects of sanctions on post-unemployment wages-consistent with a reduction in the quality of job matches-and on hours worked [11]. It also finds that these negative effects persist, and that they may increase in magnitude for up to four years after the return to work. A study on Switzerland finds a negative effect on postunemployment wages averaged over 30 months and a negative effect on job duration [2].

Because few people actually receive sanctions in most countries, there is a convincing argument that the main way sanctions are likely to influence behavior is through their threat effect, which plausibly affects all covered unemployment benefit recipients. Evidence from laboratory experiments with students is consistent with this interpretation. Of the 12 studies considered here, only two examine the effects of the threat of sanctions using observational data. One finds evidence of a shorter duration of unemployment benefits in areas in Switzerland where the threat of sanctions is stronger than elsewhere [10]. Another study, also on Switzerland, finds a similar result, along with a positive effect on job entry rates [2]. 


\section{LIMITATIONS AND GAPS}

Despite a high degree of internal validity and a high degree of agreement concerning the direction of effects on short-term outcomes, the evidence on job search monitoring and benefit sanctions remains limited in several respects. First, evidence is available only for a limited number of (mostly European) countries, often at a very local level within the country or for particular subgroups of unemployed workers, which makes it difficult to generalize about the magnitude of the effects. Second, the literature has focused on a limited set of outcomes, with few studies examining monitoring or sanction effects on earnings and other job quality measures, on exit to anything other than employment or just overall exits, or on inflows to unemployment. Third, few studies examine longerterm effects. Fourth, few studies examine evidence for heterogeneous treatment effects across different groups of unemployed workers or in different labor market contexts, at least beyond a male/female comparison, and where they have done so conclusions have been mixed. Fifth, all the studies adopt a partial-equilibrium approach, ignoring the potential for offsetting general equilibrium effects. Sixth, few studies examine evidence for sanction warning effects, despite their potential importance.

\section{SUMMARY AND POLICY ADVICE}

Job search monitoring and benefit sanctions increase the exit from unemployment benefits and job entry rates in the short term. With unemployment high in many OECD countries following the Covid-19 pandemic, job search monitoring and benefit sanctions are likely to remain important policy tools. From this perspective, the fact that some OECD countries do not monitor the job search activities of unemployment benefit recipients or do not have strong sanctioning regimes in place appears puzzling, at first glance, as do recent moves in some countries to relax such measures. But there is also some evidence that monitoring and sanctions may have negative effects on labor force participation for some workers and on post-unemployment earnings in the longer term. Looking forward, policymakers will need to confront such trade-offs in the design and implementation of monitoring and sanctions policy. Substantial gaps in the evidence base remain, however, and research that addresses these gaps could influence future policy.

\section{Acknowledgments}

The author thanks an anonymous referee and the IZA World of Labor editors for many helpful suggestions on earlier drafts. The usual disclaimers apply. Version 2 of the article updates the figures, adds new "Cons" regarding the costs imposed on monitored and sanctioned individuals, and includes two new "Further readings" and two new "Key references" [12], [13].

\section{Competing interests}

The IZA World of Labor project is committed to the IZA Code of Conduct. The author declares to have observed the principles outlined in the code. 


\section{REFERENCES}

\section{Further reading}

Hofmann, B. "Short- and long-term ex post effects of unemployment insurance sanctions." Journal of Economics and Statistics 232 (2012): 31-60.

Immervoll, H., and C. Knotz. How Demanding are Activation Requirements for Jobseekers. OECD Social, Employment and Migration Working Papers No. 215, 2018.

Lombardi, S. Threat Effects of Monitoring and Unemployment Insurance Sanctions: Evidence from Two Reforms. IFAU Working Paper No. 22, 2019.

McVicar, D. "Does job search monitoring intensity affect unemployment? Evidence from Northern Ireland." Economica 77 (2010): 296-313.

\section{Key references}

[1] Abbring, J. H., G. van den Berg, and J. C. van Ours. "The effect of unemployment insurance sanctions on the transition rate from unemployment to employment." Economic Journal 115 (2005): 602-630.

[2] Arni, P., R. Lalive, and J. C. van Ours. "How effective are unemployment benefit sanctions? Looking beyond unemployment exit." Journal of Applied Econometrics 28:7 (2013): 1153-1178.

[3] Klepinger, D. H., T. R. Johnson, and J. M. Joesch. "Effects of unemployment insurance work-search requirements: The Maryland experiment." Industrial and Labor Relations Review 56 (2002): 3-22.

[4] McVicar, D. "Job search monitoring intensity, unemployment exit and job entry: Quasiexperimental evidence from the UK." Labour Economics 15 (2008): 1451-1468.

[5] Cockx, B., and M. Dejemeppe. "Monitoring job search effort: An evaluation based on a regression discontinuity design." Labour Economics 19 (2012): 729-737.

[6] Ashenfelter, O., D. Ashmore, and O. Deschenes. "Do unemployment insurance recipients actively seek work? Evidence from randomized trials in four US states." Journal of Econometrics 125 (2005): 53-75.

[7] Micklewright, J., and G. Nagy. "The effect of monitoring unemployment insurance recipients on unemployment duration: Evidence from a field experiment." Labour Economics 17 (2010): 180-187.

[8] van den Berg, G., B. van der Klaauw, and J. C. van Ours. "Punitive sanctions and the transition rate from welfare to work." Journal of Labor Economics 22 (2004): 211-241.

[9] Svarer, M. "The effect of sanctions on exit from unemployment: Evidence from Denmark." Economica 78 (2011): 751-778.

[10] Lalive, R., J. C. van Ours, and J. Zweimuller. "The effects of benefit sanctions on the duration of unemployment." Journal of the European Economic Association 3 (2005): 1386-1417.

[11] van den Berg, G., and J. Vikström. "Monitoring job offer decisions, punishments, exit to work, and job quality." Scandinavian Journal of Economics 116:2 (2014): 284-334.

[12] Busk, H. "Sanctions and the exit from unemployment in two different benefit schemes." Labour Economics 42 (2016): 159-176.

[13] van der Klaauw, B., and J. C. van Ours. "Carrot and stick: How re-employment bonuses and benefit sanctions affect exit rates from welfare." Journal of Applied Econometrics 28 (2013): 275-296.

\section{Online extras}

The full reference list for this article is available from:

https://wol.iza.org/articles/the-impact-of-monitoring-and-sanctioning-on-unemployment-exit-andjob-finding-rates

View the evidence map for this article:

https://wol.iza.org/articles/he-impact-of-monitoring-and-sanctioning-on-unemployment-exit-andjob-finding-rates/map 